\title{
Kationowe emulsje asfaltowe. Metody wytwarzania, rodzaje i zastosowanie
}

\begin{abstract}
W artykule przedstawiono metody wytwarzania różnych rodzajów kationowych emulsji asfaltowych. Zaprezentowano proces rozpadu emulsji występujący na kruszywie, następujący podczas pracy z emulsją, a także technologie, w których na szeroką skalę stosowane są kationowe emulsje asfaltowe.
\end{abstract}

Słowa kluczowe: emulsje asfaltowe, emulgatory, kationowe emulsje asfaltowe.

\section{Cationic bitumen emulsions. Manufacturing methods, types and application}

The article presents methods of producing various types of cationic bituminous emulsions. The emulsion disintegration process on the aggregate, that follows when working with the emulsion, as well as the technologies in which cationic asphalt emulsions are applied on a large scale are presented.

Key words: bituminous emulsions, emulsifiers, cationic bituminous emulsions.

\section{Wprowadzenie}

Kationowe emulsje asfaltowe są jednym z podstawowych lepiszczy asfaltowych stosowanych w budownictwie i utrzymaniu dróg. Najczęściej produkowane są emulsje asfaltowe zawierające od 50 do $70 \%(\mathrm{~m} / \mathrm{m})$ asfaltu. Właściwości kationowych emulsji asfaltowych zależą od rodzaju i zawar- tości użytego asfaltu. Również rodzaj i ilości zastosowanego emulgatora oraz wprowadzone dodatki i modyfikatory mają wpływ na ich właściwości. Zawartość asfaltu w emulsji wpływa na jej lepkość, a przez to na możliwość jej zastosowania $[2,16-18,20,21]$.

\section{Składniki emulsji asfaltowych}

Emulsja asfaltowa jest niejednorodnym układem dyspersyjnym, składającym się z co najmniej dwóch niemieszających się cieczy silnie zdyspergowanych jedna w drugiej. W technologii drogowej na zimno pożądanym produktem jest emulsja właściwa (prosta) typu „olej w wodzie” (skrótowo oznaczana jako o/w). W takiej emulsji fazą rozproszoną (zdyspergowaną) jest asfalt, natomiast woda to faza rozpraszająca. Rozproszenie asfaltu w wodzie następuje przy zastosowaniu szybkoobrotowych młynków ścinających, zwanych młynkami koloidalnymi lub homogenizacyjnymi. W młynkach asfalt rozbijany jest na drobne cząstki różnego kształtu, które pod wpływem sił napięcia międzyfazowego przybierają postać mikroskopijnych kropli. Wymiar cząstek fazy rozproszonej w emulsji wynosi od $0,1 \mu \mathrm{m}$ do $5,0 \mathrm{~mm}$, przy czym dla dobrych emulsji pożądana jest wielkość od $0,1 \mu \mathrm{m}$ do $1,0 \mu \mathrm{m}[6,7,10,17]$.

Asfalt to substancja hydrofobowa, mająca skłonność do odpychania od siebie cząsteczek wody i dlatego napięcie międzyfazowe na granicy faz asfalt-woda jest duże i wynosi około $48 \mathrm{mN} / \mathrm{m}$. Do przeprowadzenia procesu emulgowania wymagane jest obniżenie napięcia międzyfazowego poniżej $10 \mathrm{mN} / \mathrm{m}$, które można uzyskać przez dostarczenie energii cieplnej (podgrzanie obydwu składników emulsji) oraz wprowadzenie dodatku emulgatora $[6,7,10,12,15,21,23]$.

Emulgatory są to substancje powierzchniowo czynne, obniżające napięcie międzyfazowe na granicy asfalt-woda, stabilizujące emulsję oraz poprawiające przyczepność asfaltu do kruszywa. Należą do grupy składników dodatkowych 
stosowanych w procesie wytwarzania emulsji. Ilość emulgatora stanowi w emulsji niewielką część i mieści się w granicach $0,2 \div 1,0 \%(\mathrm{~m} / \mathrm{m})[7,15]$.

Cząsteczki emulgatorów zbudowane są z dwóch części: hydrofilowej i hydrofobowej. Grupę hydrofobową stanowi najczęściej nasycony lub nienasycony alifatyczny łańcuch węglowodorowy, z większą lub mniejszą liczbą atomów węgla w łańcuchu, lub pierścień alicykliczny bądź aromatyczny. Grupa hydrofobowa nie rozpuszcza się w wodzie, lecz w substancjach organicznych.
Grupa hydrofilowa emulgatora łatwo rozpuszcza się w wodzie, natomiast nie rozpuszcza się w asfalcie. Grupę hydrofilową emulgatora mogą stanowić polarne grupy funkcyjne, np.:

- grupa karboksylowa:- $\mathrm{COOH}$,

- grupa aminowa: $-\mathrm{NH}_{2}$.

Biorąc pod uwagę ukształtowanie granicy faz asfalt-woda, można zauważyć, że wydłużona cząsteczka emulgatora zajmuje najczęściej pozycję prostopadłą do granicy obu faz. Łańcuch węglowodorowy lokuje się w asfalcie, natomiast polarna grupa funkcyjna w wodzie $[7,15,20,21,23]$.

\section{Metody wytwarzania emulsji asfaltowych}

Emulsje asfaltowe wytwarzane są dwiema podstawowymi metodami: periodyczną i ciągłą.

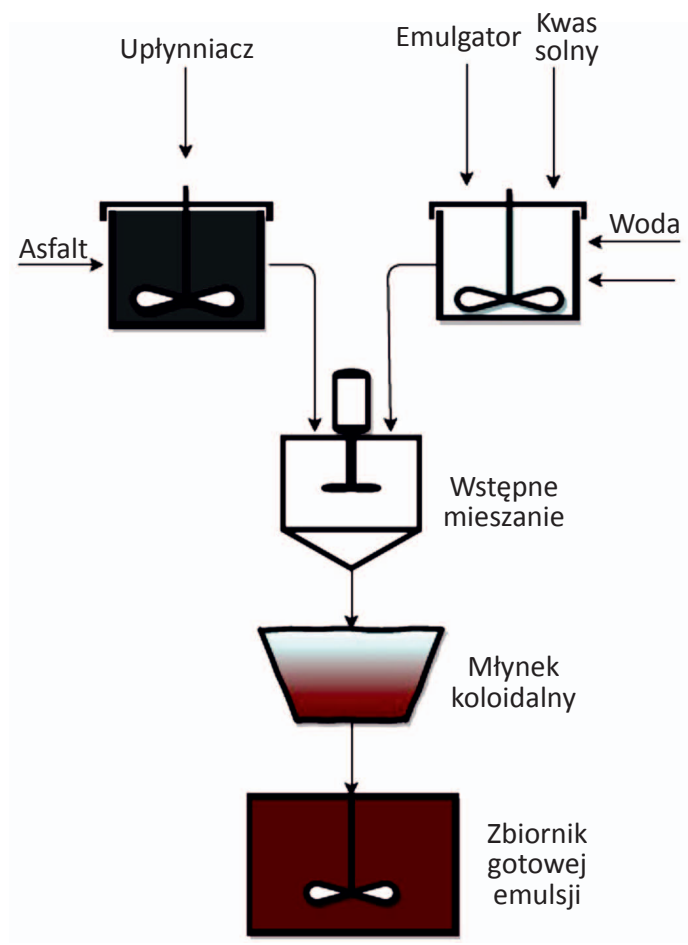

Rys. 1. Schemat periodycznej metody produkcji emulsji asfaltowej [10]

Metoda periodyczna polega na przygotowaniu w jednym zbiorniku odpowiedniej porcji asfaltu, podgrzanej do temperatury $100 \div 120^{\circ} \mathrm{C}$, łącznie z ewentualnym upłynniaczem. W drugim zbiorniku przygotowuje się wodę, podgrzaną do temperatury $80 \div 85^{\circ} \mathrm{C}$, wraz z emulgatorem $\mathrm{i}$ innymi dodatkami przewidzianymi w recepturze. Asfalt i wodę wlewa się do wspólnego zbiornika i miesza wstępnie w celu właściwego rozproszenia asfaltu w fazie wodnej. Tak wytworzoną emulsję przepuszcza się przez młynek koloidalny dla jej dobrego zdyspergowania.
Metoda periodyczna jest metodą czasochłonną i stosuje się ją głównie w pracach laboratoryjnych oraz czasami na skalę techniczną przy robotach remontowych prowadzonych w znacznym oddaleniu od wytwórni emulsji. Schemat periodycznej metody produkcji emulsji przedstawiono na rysunku 1 [10].

Metoda ciągła polega na przygotowaniu składników emulsji w taki sam sposób jak w metodzie periodycznej i podawaniu ich do młynka koloidalnego w sposób ciągły, w odpowiedniej porcji przewidzianej recepturą.

Podawanie składników emulsji do młynka może odbywać się dwoma sposobami:

- w stanie wstępnie zmieszanym, w odpowiednich proporcjach, jednym przewodem (sposób jednostrugowy),

- oddzielnie - przygotowana faza asfaltowa i faza wodna-dwoma przewodami (sposób dwustrugowy).

Schemat ciągłej metody produkcji emulsji przedstawiono na rysunku 2 [10].

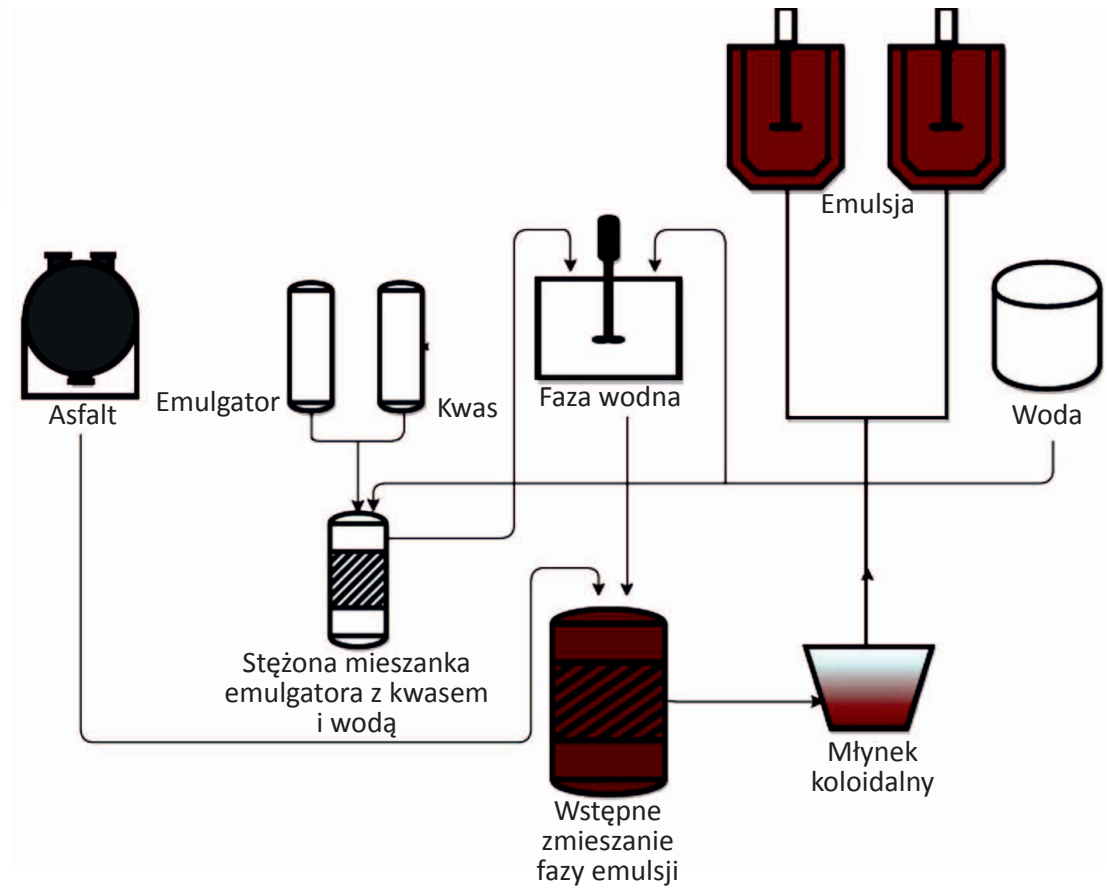

Rys. 2. Schemat ciągłej metody produkcji emulsji asfaltowej [10] 


\section{Rodzaje kationowych emulsji asfaltowych}

Wśród kationowych emulsji asfaltowych można wyodrębnić ich dwa podstawowe rodzaje: modyfikowane i niemodyfikowane.

Emulsje niemodyfikowane zawierają asfalt, emulgator, wodę i dodatki. Asfalt stosowany do produkcji emulsji powinien spełniać wymagania normy PN-EN 12591 [25] oraz, w zależności od przeznaczenia emulsji, charakteryzować się penetracją w zakresie $(40 \div 300) \times 0,1 \mathrm{~mm}$. Emulsje wytwarzane są w sposób ciągły, polegający na podgrzaniu asfaltu z upłynniaczem do temperatury $100 \div 150^{\circ} \mathrm{C}$, w celu zbliżenia jego lepkości do lepkości wody. Wodę wraz z kwasem solnym i emulgatorem ogrzewa się do temperatury $80 \div 85^{\circ} \mathrm{C}$. Średnia arytmetyczna temperatury asfaltu i wody powinna wynosić około $100^{\circ} \mathrm{C}$, co zapobiega pienieniu. Wymieszane składniki podawane są do młynka koloidalnego, w którym następuje zdyspergowanie asfaltu w wodzie. Schemat produkcji niemodyfikowanych emulsji asfaltowych przedstawiono na rysunku 3. Gotowa emulsja z młynka koloidalnego jest transportowana do zbiorników. Przed sprzedażą emulsję przepompowuje się do zbiorników stojących pionowych, $\mathrm{z}$ wymuszonym powolnym mieszaniem $[7,12]$.

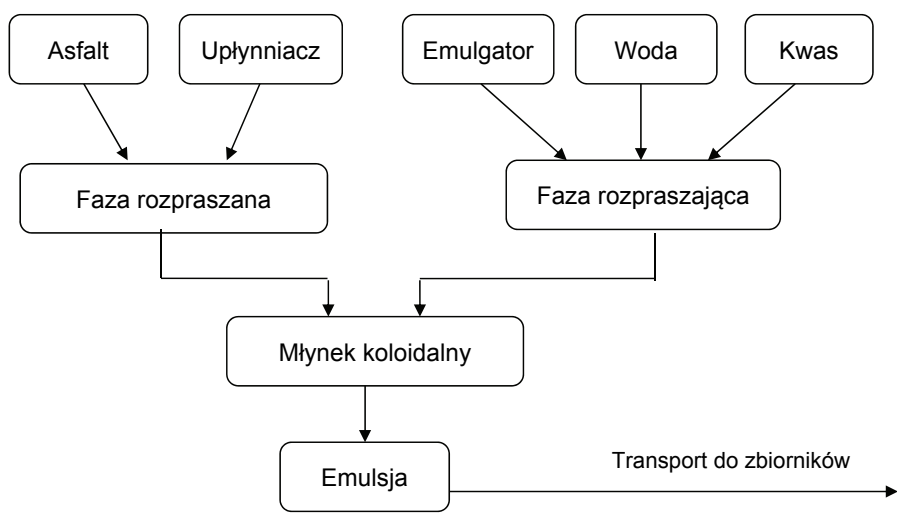

Rys. 3. Schemat produkcji niemodyfikowanych emulsji asfaltowych [7]

Emulsje modyfikowane wytwarza się według tego samego schematu co emulsje niemodyfikowane, $\mathrm{z}$ wyjątkiem procesu dodawania modyfikatora. Rozróżnia się dwa typy emulsji modyfikowanych:

- jednofazowe - wytwarzane z asfaltu modyfikowanego; charakteryzują się tym, że faza rozproszona składa się tylko z kropelek modyfikowanego polimeroasfaltu (rysunek 4),

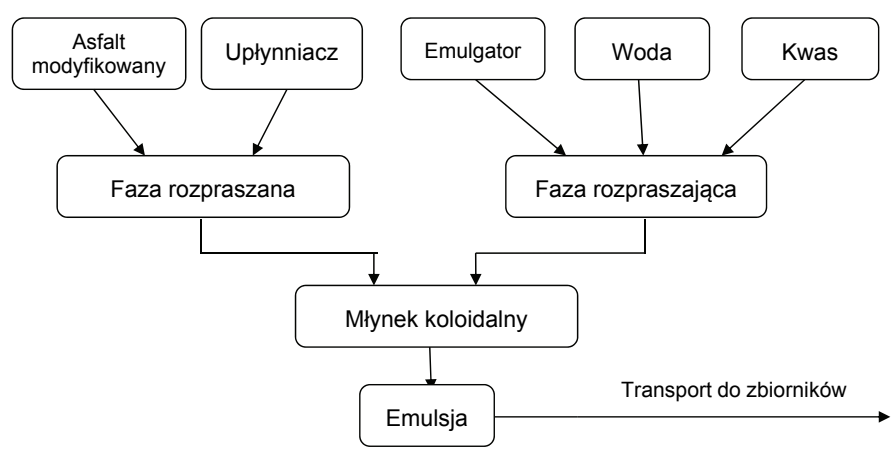

Rys. 4. Schemat produkcji modyfikowanych jednofazowych emulsji asfaltowych $[7,15]$

- dwufazowe - modyfikator dodaje się w postaci lateksu; charakteryzują się tym, że faza rozproszona składa się z dwóch rodzajów kropelek: asfaltu i środka modyfikującego (lateksu). Dodawanie lateksu można wykonać przez:

- zdyspergowanie w fazie wodnej (faza rozpraszająca),

- wtryskiwanie bezpośrednio do młynka koloidalnego,

- zdyspergowanie w wytworzonej emulsji asfaltowej.

Schemat produkcji emulsji dwufazowej przedstawiono na rysunku $5[7,15]$.

Metoda zdyspergowania lateksu w fazie wodnej umożliwia regulację $\mathrm{pH}$ w trakcie procesu produkcji oraz pozwala na uzyskanie dobrej jednorodnej dyspersji. Metoda wtryskiwania lateksu bezpośrednio do asfaltu może powodować zaburzenia w działaniu młyna koloidalnego. Metoda dyspersji lateksu w wytworzonej emulsji asfaltowej daje produkt o obniżonej stabilności, ze względu na mieszanie dwóch emulsji o różnych właściwościach [7].

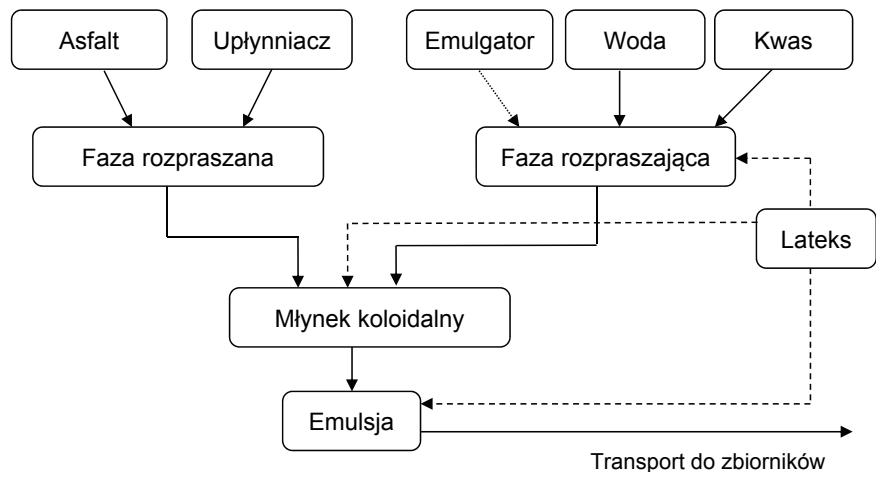

Rys. 5. Schemat produkcji modyfikowanych dwufazowych emulsji asfaltowych $[7,15]$

\section{Budowa emulsji - warunki tworzenia emulsji}

Stosowane do wytworzenia kationowych emulsji asfaltowych emulgatory kationowe, rozpuszczając się w asfalcie, dostarczają cząstkom asfaltu ładunki dodatnie i w konse- kwencji pełnią rolę stabilizatora. Wokół dodatnio naładowanych cząstek asfaltu grupują się aniony. Naładowanie cząstek emulsji jednoimiennymi ładunkami elektrycznymi zapobiega 
procesowi ich łączenia, czyli koagulacji emulsji. Jako emulgatory emulsji kationowych najczęściej stosowane są aminy alifatyczne $\mathrm{w}$ formie ich soli z kwasami nieorganicznymi (najczęściej $\mathrm{HCl})$.

Typowy emulgator kationowy, w uproszczonej formie, można przedstawić w postaci wzoru:

$$
\mathrm{R}-\mathrm{NH}_{3}^{+} \mathrm{Cl}^{-}
$$

w którym:

$\mathrm{R}$ - łańcuch węglowodorowy, najczęściej tłuszczowy (część hydrofobowa cząsteczki),

$\mathrm{NH}_{3}^{+} \mathrm{CL}^{-}$- część hydrofilowa cząsteczki.

W roztworze wodnym ulega on dysocjacji, zgodnie z reakcją:

$$
\mathrm{R}-\mathrm{NH}_{3}^{+} \mathrm{Cl}^{-} \rightarrow \mathrm{R}-\mathrm{NH}_{3}^{+}+\mathrm{Cl}^{-}
$$

W trakcie wytwarzania emulsji kationy $\mathrm{R}-\mathrm{NH}_{3}^{+}$są adsorbowane przez cząstki asfaltu, przy czym część hydrofobowa (łańcuch węglowodorowy) lokuje się wewnątrz cząst- ki asfaltu, natomiast grupa $\mathrm{NH}_{3}^{+}$na granicy powierzchni asfalt-woda. Aniony chlorkowe pozostają w fazie wodnej (rysunek 6) [7, 11, 16, 17].

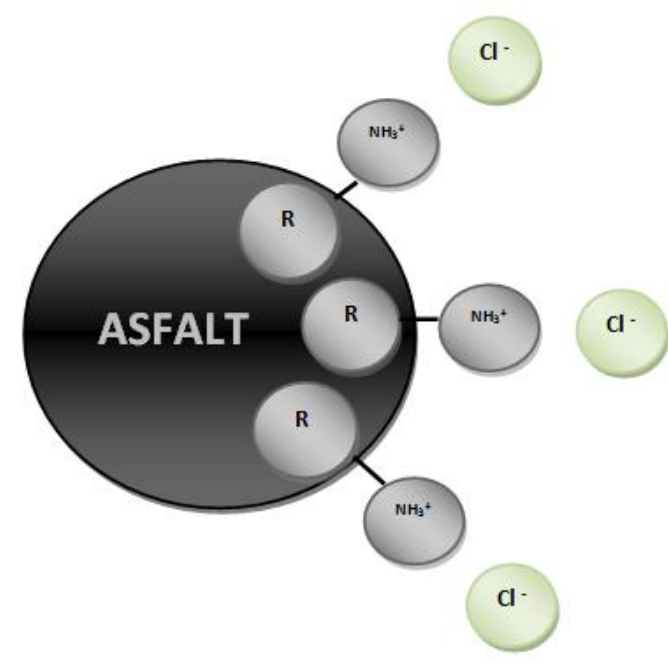

Rys. 6. Schemat pojedynczej cząstki asfaltu w emulsji kationowej

\section{Proces rozpadu emulsji asfaltowej}

Jest to proces, w którym faza zdyspergowana (asfalt) oddziela się od fazy rozpraszającej (wody). Może on nastąpić wskutek:

- odparowania wody,

- reakcji chemicznej z materiałem mineralnym,

- wstrząsania,

- przepompowywania,

- ogrzewania powyżej temperatury $80^{\circ} \mathrm{C}$,

- zmiany wartości pH.

Najczęściej spotykanym w drogownictwie rodzajem rozpadu emulsji asfaltowych jest rozpad zachodzący w wyniku reakcji chemicznej z materiałem mineralnym, przy czym woda przemieszcza się na zewnątrz tworzącej się błonki asfaltu i oddziela od niej. Powierzchnia materiału mineralnego, takiego jak np.: kruszywo, pod wpływem wilgoci ulega międzyfazowej jonizacji, w wyniku czego na jego powierzchni pojawiają się jony różne w zależności od rodzaju kruszywa.

Na kruszywie zasadowym, którego głównym składnikiem jest węglan wapnia, na skutek dysocjacji pojawiają się kationy wapniowe $\mathrm{Ca}^{2+} \mathrm{i}$ aniony węglanowe $\mathrm{CO}_{3}^{2-}$. W wyniku reakcji emulgatora znajdującego się na powierzchni cząstek asfaltu z powierzchnią kruszywa powstaje nierozpuszczalny węglan aminy:

$$
\begin{array}{cccc}
2 \mathrm{R}-\mathrm{NH}_{3}^{+} \mathrm{Cl}^{-} & +\mathrm{CaCO}_{3} & \rightarrow \mathrm{CaCl}_{3}+\left(\mathrm{R}-\mathrm{NH}_{3}^{+}\right)_{2}+\mathrm{CO}_{3} \\
\text { asfalt }+ & \text { kruszywo } & \text { rozpuszczalny } & \text { nierozpuszczalny } \\
\text { emulgator } & \text { zasadowe } & \text { chlorek wapnia } & \text { węglan aminy }
\end{array}
$$

W reakcji chemicznej następuje zobojętnienie ładunków i rozpad emulsji, ponieważ cząstki asfaltu łączą się ze sobą na powierzchni kruszywa i występuje zjawisko przyczepności asfaltu do kruszywa.

Na kruszywie kwaśnym, np.: kwarcyt, granit, którego głównym składnikiem są różne związki krzemu $\left(\mathrm{SiO}_{2}\right.$; krzemiany), na skutek jonizacji w obecności fazy wodnej emulsji na powierzchni pojawiają się aniony krzemianowe $\mathrm{SiO}_{4}^{4}$ silnie $\mathrm{z}$ nią związane. $\mathrm{W}$ wyniku reakcji emulgatora znajdującego się na powierzchni cząstek asfaltu z powierzchnią kruszywa powstanie nierozpuszczalny krzemian aminy:

$$
\begin{aligned}
& 2 \mathrm{R}-\mathrm{NH}_{3}^{+} \mathrm{Cl}^{-}+\mathrm{H}_{4} \mathrm{SiO}_{4} \rightarrow 2 \mathrm{HCl}+\left(\mathrm{R}-\mathrm{NH}_{3}^{+}\right)_{2} \mathrm{SiO}_{4}+\mathrm{H}_{2} \\
& \text { asfalt }+\quad \text { kruszywo rozpuszczalny nierozpuszczalny } \\
& \text { emulgator kwaśne kwas solny krzemian aminy }
\end{aligned}
$$

Na skutek rozpadu emulsji na powierzchni kruszywa powstaje silne wiązanie adhezyjne pomiędzy kruszywem a asfaltem $[7,11,12,16]$.

\section{Zastosowanie kationowych emulsji asfaltowych}

Kationowe emulsje asfaltowe wykorzystywane są przy budowie i remontach dróg wszystkich kategorii ruchu. Różnorodność właściwości emulsji, wynikająca z zastosowania emulgatorów i różnych asfaltów (w tym także modyfikowa- nych polimerami), powoduje, że są one wykorzystane w wielu technologiach robót drogowych.

Technologiami, w których na szeroką skalę stosowane są kationowe emulsje asfaltowe, są: 
- złączenia/skropienia międzywarstwowe,

- międzyfazowe utrwalenie,

- remonty cząstkowe,

- cienkie warstwy asfaltowe na zimno (slurry surfacing),

- mieszanki mineralno-asfaltowe,

- recykling z emulsją asfaltową (mieszanka mineralno-cementowo-emulsyjna) [1, 2, 3, 8, 13, 14, 19, 21, 24].

Złączenia/skropienia międzywarstwowe wykonywane są w konstrukcjach wielowarstwowych w celu związania nowej warstwy asfaltowej z podłożem. Złączenie warstw asfaltowych spełnia podwójną funkcję:

- zwiększa wytrzymałość zespołu warstw nawierzchni,

- uniemożliwia penetrację wody pomiędzy warstwami.

Skropienia dokonuje się skrapiarkami, co daje gwarancję równomiernego skropienia odpowiednią ilością emulsji.

Złączenie warstw wykonywane jest z emulsji wytworzonej z asfaltem o penetracji zbliżonej do tej, jaką charakteryzował się asfalt używany do wytworzenia tych warstw. Pierwsze złączenie warstw realizowane jest na powierzchni podbudowy. Zadaniem skropienia jest:

- sklejenie pierwszej warstwy asfaltowej z podbudową mineralną lub asfaltową,

- zabezpieczenie podbudowy przed wodą wpływającą pod warstwę asfaltową,

- stworzenie warstwy odcinającej porowatą podbudowę od pierwszej warstwy asfaltowej, co zmniejsza wchłanianie lepiszcza z warstwy asfaltowej,

- związanie luźnych ziaren podbudowy.

W kraju do złączania wszystkich warstw asfaltowych wbudowywanych w nawierzchnię na drogach obciążonych ruchem od KR1 do KR7 wykorzystywana jest kationowa emulsja asfaltowa C 60 BP 3 ZM. W trakcie pracy warto pamiętać, aby pokrycie zostało wykonane równomiernie, lepiszcze nie było użyte w nadmiarze, a rozpad emulsji został zakończony przed ułożeniem następnej warstwy z betonu asfaltowego [16, 21, 24].

Mieddzyfazowe utrwalenie polega na skropieniu nawierzchni warstwą emulsji asfaltowej, równomiernym rozłożeniu warstwy grysu i zagęszczeniu walcem ogumionym. Podstawowymi rodzajami międzyfazowego utrwalenia są:

- pojedyncze międzyfazowe utrwalenie - polega na skropieniu nawierzchni drogowej warstwą lepiszcza i pokryciu jej warstwą grysów, które wiążą się z lepiszczem; wykonywane jest na drogach, gdzie nie pojawiają się największe obciążenia;

- klinowe międzyfazowe utrwalenie - polega na skropieniu nawierzchni drogowej warstwą lepiszcza, ułożeniu pierwszej warstwy większych grysów, a następnie - drugiej warstwy drobniejszych grysów, które klinują większe grysy w danej pozycji, tworząc stabilny układ warstw; wykonywane jest na drogach, gdzie ruch jest szczególnie ciężki lub szybki;

- podwójne międzyfazowe utrwalenie - polega na dwukrotnym wykonaniu zabiegu pojedynczego międzyfazowego utrwalenia; wykonywane jest na drogach obciążonych co najmniej ruchem ciężkim;

- międzyfazowe utrwalenie typu sandwich - polega na ułożeniu pierwszej warstwy grysów bezpośrednio na podłożu, bez wcześniejszego skropienia lepiszczem, a następnie wykonaniu typowego międzyfazowego utrwalenia; wykonywane jest na nawierzchniach z nadmiarem lepiszcza. Międzyfazowe utrwalenie przeprowadzane jest na drogach, na których wskutek działania czynników atmosferycznych pojawiają się przełomy i dziury. Celem międzyfazowego utrwalenia jest:

- powstanie szorstkiej warstwy ścieralnej,

- uszczelnienie nawierzchni, powstrzymanie jej destrukcji, - poprawienie estetyki drogi, uzyskanie jednolitego wyglądu nawierzchni.

Przy remontowaniu nawierzchni drogowej metodą międzyfazowego utrwalenia należy uwzględnić obciążenie ruchem, warunki topograficzne i atmosferyczne oraz rodzaj i stan podłoża $[16,24]$.

Remonty czastkowe wykonywane są podobnie jak międzyfazowe utrwalenia (skropienie podłoża, rozłożenie grysów, zagęszczenie), ale tylko w uszkodzonych miejscach, a nie na całej powierzchni. Naprawę przeprowadza się w następującej kolejności:

- oczyszczenie miejsca uszkodzenia sprężonym powietrzem,

- skropienie emulsją pod ciśnieniem,

- wtryskiwanie w uszkodzenie grysu otoczonego emulsją,

- posypanie miejsca naprawy suchym grysem.

Zaletą takiej technologii jest:

- bardzo dobra jakość naprawy wykonanej otoczonym grysem,

- wysoka wydajność,

- bezpieczeństwo,

- oszczędność materiałów,

- natychmiastowa gotowość do pracy sprzętu i jego duża mobilność [16, 26].

Cienkie warstwy na zimno (slurry surfacing) to technologia polegająca na wykonaniu dywanika asfaltowego na zimno przy użyciu mieszanki mineralno-asfaltowej. Mieszanka jest wytwarzana i wbudowywana na miejscu. Cienkie warstwy asfaltowe na zimno stosowane są w pracach utrzymaniowych, przy rekonstrukcji, ale także przy budowie nowych dróg. Zastosowanie tej technologii pozwala na:

- ulepszenie tekstury i poprawę szorstkości,

- poprawienie równości lekko zdeformowanych nawierzchni,

- wypełnienie kolein, 
- otrzymanie jednorodnej, estetycznie wyglądającej nawierzchni,

- uszczelnienie lekko spękanych powierzchni,

- zamknięcie nawierzchni i poprawę odporności na przenikanie wody,

- w przypadku nowych dróg - wykonanie warstwy ścieralnej. Cienkie warstwy na zimno mogą być układane na wszelkiego rodzaju nawierzchniach, zarówno podatnych, jak i sztywnych. Technologia ta stosowana jest na drogach o pełnym zakresie obciążenia ruchem, włącznie z nawierzchniami autostradowymi [13, 14, 16, 24].

Mieszanki mineralno-asfaltowe są wytwarzane z różnego rodzaju kruszyw i emulsji asfaltowych, produkowanych z zastosowaniem silnie upłynnionego lub fluksowanego asfaltu. Wiązanie asfaltu w mieszankach następuje po ich rozłożeniu i zagęszczeniu. Stosuje się je do wykonywania remontów cząstkowych w okresie jesienno-wiosennym, polegających na uzupełnianiu ubytków uszkodzonych nawierzchni, a także usuwania przekopów, kanałów, przepustów kablowych. Mieszanka pakowana jest w worki polipropylenowe, co pozwala na długotrwałe składowanie.

Wbudowanie polega na oczyszczeniu wgłębienia i zasypaniu ręcznie masy. Po nałożeniu warstwy kruszywa o grubości $5 \mathrm{~cm}$ należy mieszankę zagęścić (ubić). Po każdym następnym nałożeniu kolejnej warstwy trzeba mieszankę ponow- nie zagęścić. Po zapełnieniu całego wgłębienia powierzchnię wyrównuje się i zagęszcza przy użyciu wibratora międzyfazowego. Po wykonaniu tych prac nawierzchnia jest gotowa do eksploatacji. Wbudowanie mieszanki może się odbywać w temperaturze od -20 do $+30^{\circ} \mathrm{C}[16,24]$.

Recykling z emulsją asfaltową (mieszanka mineralno-cementowo-emulsyjna) wykonywany jest w technologii na zimno z zastosowaniem emulsji asfaltowej. Sfrezowana lub pokruszona mieszanka mineralno-asfaltowa, pochodząca ze starej zniszczonej nawierzchni, jest mieszana sposobem na zimno z cementem i emulsją asfaltową w warunkach optymalnej wilgotności. Mieszanka znajduje zastosowanie w warstwach podbudowy nawierzchni drogowej.

Stosowanie emulsji asfaltowych daje następujące korzyści:

- techniczne - możliwość wykorzystania emulsji w wielu technologiach drogowych; ich stosowanie daje dobre jakościowo rezultaty,

- ekonomiczne - wyeliminowanie nadmiernego zużycia energii niezbędnej przy podgrzewaniu kruszyw i lepiszcza w technologiach na gorąco, a tym samym - obniżenie kosztów robót wykonywanych z użyciem emulsji asfaltowych,

- ekologiczne - emulsje asfaltowe powodują wyeliminowanie z technologii drogowych rozpuszczalników i związków węglowodorowych szkodliwych dla środowiska $[16,24]$.

\section{Właściwości kationowych emulsji asfaltowych}

Badania właściwości kationowych emulsji asfaltowych wykonywane są zgodnie z normami powołanymi w załączniku krajowym NA do normy PN-EN 13808:2013. W załączniku tym przedstawiono wymagania dla dziewięciu rodzajów krajowych kationowych emulsji asfaltowych, podzielonych w zależności od zalecanego zastosowania [3-5, $9,19,22,26]$.
Wymagania dla dwóch rodzajów kationowych emulsji asfaltowych, wytworzonych z użyciem asfaltu modyfikowanego polimerami, stosowanych do powierzchniowych utrwaleń i remontów cząstkowych, przedstawiono w tablicy 1, a dla lepiszczy odzyskanych, stabilizowanych i starzonych z wyżej wymienionych rodzajów kationowych emulsji asfaltowych - w tablicy 2 [26].

Tablica 1. Wymagania dla kationowych emulsji asfaltowych modyfikowanych polimerami do powierzchniowych utrwaleń i remontów cząstkowych [26]

\begin{tabular}{|c|c|c|c|c|}
\hline \multicolumn{3}{|c|}{ Oznaczenie kodowe wyrobu } & C 65 BP 3 PU/RC & C 69 BP 3 PU \\
\hline Właściwość & Metoda badania & Jednostka & \multicolumn{2}{|c|}{ Wymaganie (klasa) } \\
\hline Zawartość lepiszcza & EN 1428 & $\%(m / m)$ & 63 do $67(7)$ & 67 do $71(9)$ \\
\hline Indeks rozpadu & EN 13075-1 & $\mathrm{g} / 100 \mathrm{~g}$ & $70 \div 155(3)$ & $70 \div 155(3)$ \\
\hline Czas mieszania & EN $13075-2$ & $\mathrm{~s}$ & $\mathrm{NR}^{\mathrm{a}}(0)$ & $\mathrm{NR}^{\mathrm{a}}(0)$ \\
\hline Stabilność podczas mieszania z cementem & EN 12848 & $\mathrm{~g}$ & $\mathrm{NR}^{\mathrm{a}}(0)$ & $\mathrm{NR}^{\mathrm{a}}(0)$ \\
\hline Pozostałość na sicie, sito $0,5 \mathrm{~mm}$ & EN 1429 & $\%(m / m)$ & $\leq 0,2(3)$ & $\leq 0,2(3)$ \\
\hline Czas wypływu $\varnothing 2 \mathrm{~mm} \mathrm{w} 40^{\circ} \mathrm{C}$ & EN 12846-1 & $\mathrm{s}$ & $40 \div 130(4)$ & $\mathrm{NR}^{\mathrm{a}}(0)$ \\
\hline Czas wypływu $\varnothing 4 \mathrm{~mm} \mathrm{w} 40^{\circ} \mathrm{C}$ & EN 12846-1 & $\mathrm{s}$ & $\mathrm{NR}^{\mathrm{a}}(0)$ & $5-70(5)$ \\
\hline Czas wypływu $\varnothing 4 \mathrm{~mm} \mathrm{w} 50^{\circ} \mathrm{C}$ & EN 12846-1 & $\mathrm{s}$ & $\mathrm{NR}^{\mathrm{a}}(0)$ & $\mathrm{NR}^{\mathrm{a}}(0)$ \\
\hline Lepkość dynamiczna & EN 14896 & $\mathrm{mPa} \times \mathrm{s}$ & $\mathrm{NR}^{\mathrm{a}}(0)$ & $\mathrm{NR}^{\mathrm{a}}(0)$ \\
\hline
\end{tabular}


cd. Tablica 1

\begin{tabular}{|c|c|c|c|c|}
\hline \multicolumn{3}{|c|}{ Oznaczenie kodowe wyrobu } & C 65 BP 3 PU/RC & C 69 BP 3 PU \\
\hline Właściwość & Metoda badania & Jednostka & \multicolumn{2}{|c|}{ Wymaganie (klasa) } \\
\hline Przyczepność do kruszywa referencyjnego ${ }^{\mathrm{b}}$ & EN 13614 & $\begin{array}{l}\% \text { pokrycia } \\
\text { powierzchni }\end{array}$ & $\geq 75(2)$ & $\geq 75(2)$ \\
\hline Zdolność do penetracji & EN 12849 & $\min$ & $\mathrm{NR}^{\mathrm{a}}(0)$ & $\mathrm{NR}^{\mathrm{a}}(0)$ \\
\hline Zawartość olejów destylacyjnych & EN 1431 & $\%(m / m)$ & $\mathrm{NR}^{\mathrm{a}}(0)$ & $\mathrm{NR}^{\mathrm{a}}(0)$ \\
\hline Pozostałość na sicie, sito $0,16 \mathrm{~mm}$ & EN 1429 & $\%(m / m)$ & $\mathrm{NR}^{\mathrm{a}}(0)$ & $\mathrm{NR}^{\mathrm{a}}(0)$ \\
\hline Czas wypływu w $85^{\circ} \mathrm{C}$ & EN 16345 & $\mathrm{~s}$ & $\mathrm{NR}^{\mathrm{a}}(0)$ & $\mathrm{NR}^{\mathrm{a}}(0)$ \\
\hline $\begin{array}{l}\text { Stabilność magazynowania na sicie ( } 7 \text { dni } \\
\text { magazynowania - sito } 0,5 \mathrm{~mm})\end{array}$ & EN 1429 & $\%(m / m)$ & $\leq 0,2(3)$ & $\leq 0,2(3)$ \\
\hline Sedymentacja po 7 dniach magazynowania & EN 12847 & $\%(m / m)$ & $\mathrm{NR}^{\mathrm{a}}(0)$ & $\mathrm{NR}^{\mathrm{a}}(0)$ \\
\hline
\end{tabular}

${ }^{a} \mathrm{NR}-$ No Requirement (brak wymagań). ${ }^{\mathrm{b}}$ Badanie na kruszywie bazaltowym.

Tablica 2. Wymagania dla lepiszczy odzyskanych, stabilizowanych i poddanych starzeniu, z kationowych emulsji asfaltowych modyfikowanych polimerami do powierzchniowych utrwaleń i remontów cząstkowych [26]

\begin{tabular}{|c|c|c|c|c|}
\hline \multicolumn{3}{|c|}{ Oznaczenie kodowe wyrobu } & C 65 BP 3 PU/RC & C 69 BP 3 PU \\
\hline Właściwość & Metoda badania & Jednostka & \multicolumn{2}{|c|}{ Wymaganie (klasa) } \\
\hline Lepiszcze odzyskane przez odparowanie & EN 13074-1 & & & \\
\hline Penetracja w $25^{\circ} \mathrm{C}$ & EN 1426 & $0,1 \mathrm{~mm}$ & $\mathrm{NR}^{\mathrm{a}}(0)$ & $\mathrm{NR}^{\mathrm{a}}(0)$ \\
\hline Temperatura mięknienia & EN 1427 & ${ }^{\circ} \mathrm{C}$ & $\mathrm{NR}^{\mathrm{a}}(0)$ & $\mathrm{NR}^{\mathrm{a}}(0)$ \\
\hline Energia kohezji & $\begin{array}{l}\text { EN } 13589 \\
\text { EN } 13703\end{array}$ & $\mathrm{~J} / \mathrm{cm}^{2}$ & $\mathrm{NR}^{\mathrm{a}}(0)$ & $\mathrm{NR}^{\mathrm{a}}(0)$ \\
\hline Kohezja (wahadło) & EN 13588 & $\mathrm{~J} / \mathrm{cm}^{2}$ & $\mathrm{NR}^{\mathrm{a}}(0)$ & $\mathrm{NR}^{\mathrm{a}}(0)$ \\
\hline Temperatura łamliwości & EN 12593 & ${ }^{\circ} \mathrm{C}$ & $\mathrm{NR}^{\mathrm{a}}(0)$ & $\mathrm{NR}^{\mathrm{a}}(0)$ \\
\hline Nawrót sprężysty w $10^{\circ} \mathrm{C}$ & EN 13398 & $\%$ & $\mathrm{NR}^{\mathrm{a}}(0)$ & $\mathrm{NR}^{\mathrm{a}}(0)$ \\
\hline Nawrót sprężysty w $25^{\circ} \mathrm{C}$ & EN 13398 & $\%$ & $\mathrm{NR}^{\mathrm{a}}(0)$ & $\mathrm{NR}^{\mathrm{a}}(0)$ \\
\hline Lepiszcze odzyskane i stabilizowane & $\begin{array}{l}\text { EN 13074-1 } \\
\text { EN 13074-2 }\end{array}$ & & & \\
\hline Penetracja $\mathrm{w} 25^{\circ} \mathrm{C}$ & EN 1426 & $0,1 \mathrm{~mm}$ & $\leq 150(4)$ & $\leq 150(4)$ \\
\hline Temperatura mięknienia & EN 1427 & ${ }^{\circ} \mathrm{C}$ & $\geq 43(6)$ & $\geq 43(6)$ \\
\hline Energia kohezji & $\begin{array}{l}\text { EN } 13589 \\
\text { EN } 13703\end{array}$ & $\mathrm{~J} / \mathrm{cm}^{2}$ & $\mathrm{NR}^{\mathrm{a}}(0)$ & $\mathrm{NR}^{\mathrm{a}}(0)$ \\
\hline Kohezja (wahadło) & EN 13588 & $\mathrm{~J} / \mathrm{cm}^{2}$ & $\mathrm{DV}^{\mathrm{b}}(1)$ & $\mathrm{DV}^{\mathrm{b}}(1)$ \\
\hline Temperatura łamliwości & EN 12593 & ${ }^{\circ} \mathrm{C}$ & $\mathrm{NR}^{\mathrm{a}}(0)$ & $\mathrm{NR}^{\mathrm{a}}(0)$ \\
\hline Nawrót sprężysty w $10^{\circ} \mathrm{C}$ & EN 13398 & $\%$ & $\mathrm{NR}^{\mathrm{a}}(0)$ & $\mathrm{NR}^{\mathrm{a}}(0)$ \\
\hline Nawrót sprężysty w $25^{\circ} \mathrm{C}$ & EN 13398 & $\%$ & $\geq 50(5)$ & $\geq 50(5)$ \\
\hline $\begin{array}{l}\text { Lepiszcze odzyskane, stabilizowane } \\
\text { i poddane starzeniu }\end{array}$ & $\begin{array}{c}\text { EN 13074-1 } \\
\text { EN 13074-2 } \\
\text { EN 14769 }\end{array}$ & & & \\
\hline Penetracja $\mathrm{w} 25^{\circ} \mathrm{C}$ & EN 1426 & $0,1 \mathrm{~mm}$ & $\mathrm{NR}^{\mathrm{a}}(0)$ & $\mathrm{NR}^{\mathrm{a}}(0)$ \\
\hline Temperatura mięknienia & EN 1427 & ${ }^{\circ} \mathrm{C}$ & $\mathrm{NR}^{\mathrm{a}}(0)$ & $\mathrm{NR}^{\mathrm{a}}(0)$ \\
\hline Energia kohezji & $\begin{array}{l}\text { EN } 13589 \\
\text { EN } 13703\end{array}$ & $\mathrm{~J} / \mathrm{cm}^{2}$ & $\mathrm{NR}^{\mathrm{a}}(0)$ & $\mathrm{NR}^{\mathrm{a}}(0)$ \\
\hline Kohezja (wahadło) & EN 13588 & $\mathrm{~J} / \mathrm{cm}^{2}$ & $\mathrm{NR}^{\mathrm{a}}(0)$ & $\mathrm{NR}^{\mathrm{a}}(0)$ \\
\hline Temperatura łamliwości & EN 12593 & ${ }^{\circ} \mathrm{C}$ & $\mathrm{NR}^{\mathrm{a}}(0)$ & $\mathrm{NR}^{\mathrm{a}}(0)$ \\
\hline Nawrót sprężysty w $10^{\circ} \mathrm{C}$ & EN 13398 & $\%$ & $\mathrm{NR}^{\mathrm{a}}(0)$ & $\mathrm{NR}^{\mathrm{a}}(0)$ \\
\hline Nawrót sprężysty w $25^{\circ} \mathrm{C}$ & EN 13398 & $\%$ & $\mathrm{NR}^{\mathrm{a}}(0)$ & $\mathrm{NR}^{\mathrm{a}}(0)$ \\
\hline
\end{tabular}

${ }^{a} \mathrm{NR}$ - No Requirement (brak wymagań). ${ }^{\mathrm{b}} \mathrm{DV}$ - Declared Value (wartość deklarowana). 


\section{Podsumowanie}

Kationowe emulsje asfaltowe są jednym z podstawowych lepiszczy asfaltowych, wykorzystywanym przy budowie i remontach dróg wszystkich kategorii ruchu. Podstawowymi składnikami kationowych emulsji asfaltowych są: asfalt, woda, emulgator oraz modyfikator. Emulgator w emulsji spełnia trzy funkcje:

- obniża napięcie międzyfazowe między dwiema fazami, tj. wodą i asfaltem,

- stabilizuje emulsję,

- poprawia przyczepność asfaltu do kruszywa.

Kationowe emulsje asfaltowe niemodyfikowane oraz modyfikowane można wytwarzać dwiema metodami: ciągłą i perio- dyczną. Metoda ciągła stosowana jest w wytwórniach emulsji na dużą i średnią skalę produkcyjną, natomiast metoda periodyczna przy prowadzeniu prac naukowych i doświadczalnych oraz czasami na skalę techniczną - przy robotach remontowych prowadzonych w znacznym oddaleniu od wytwórni emulsji.

Różnorodność właściwości emulsji, wynikająca z zastosowania emulgatorów i asfaltów o różnych właściwościach, powoduje, że są one wykorzystane w wielu technologiach robót drogowych. W Polsce w oparciu o wymagania zawarte w załączniku krajowym NA do normy PN-EN 13808:2013-10 produkowanych jest dziewięć rodzajów kationowych emulsji asfaltowych do różnych zastosowań.

Prosimy cytować jako: Nafta-Gaz 2017, nr 6, s. 438-445, DOI: 10.18668/NG.2017.06.09

Artykuł nadesłano do Redakcji 19.12.2016 r. Zatwierdzono do druku 5.04.2017 r.

Artykuł powstał na podstawie pracy statutowej pt.: Wpływ emulgatorów na właściwości kationowych emulsji asfaltowych - praca INiG - PIB na zlecenie MNiSW; nr zlecenia: 0077/TO/17, nr archiwalny: DK-4100-71/16.

\section{Literatura}

[1] Andrzejewski P., Östlund J.A.: Zastosowanie technologii ,, slurry seal" do konserwacji nawierzchni i wzmacniania konstrukcji drogi. XIII Konferencja „Emulsje asfaltowe w drogownictwie”, Ustroń, 4-6.03.2015.

[2] Asphalt Emulsion; http://hawaiiasphalt.org/wp/wp-content/uploads/AEMA-Brochure.pdf (dostęp: lipiec 2016).

[3] Berg P.: Kationowe emulsje asfaltowe. Chaos w specyfikacjach, czyli... samo życie. Polskie Drogi 2011, nr 7-8, s. 40-42.

[4] Brion Y.: Emulsje indeks rozpadu. XI Konferencja „Emulsje asfaltowe w drogownictwie", Ustroń, 26-28.02.2014.

[5] Delmar S.: Asphalt Emulsion Technology. Transportation research circular, nr E-C102, sierpień 2006.

[6] Duncan J. Shaw: Introduction to colloid and surface chemistry. Oxford: Butterworth-Heinemann 1992, s. 266.

[7] Gaweł I., Kalabińska M., Piłat J.: Asfalty drogowe. Wydawnictwa Komunikacji i Łączności, Warszawa 2001.

[8] Hariasz J.: Emulsje 2013 - podsumowanie. XI Konferencja „Emulsje asfaltowe w drogownictwie”, Ustroń, 26-28.02.2014.

[9] Isacsson U.: A compilation of laboratory methods for studying stability of bitumen emulsions. Matériaux et Constructions 1986 , vol. 18, s. 228-236.

[10] Luszawski S.: Nawierzchniowe emulsje asfaltowe. Wydawnictwa Komunikacji i Łączności, Warszawa 1973.

[11] Mieczkowski P.: Emulsje asfaltowe $w$ drogownictwie. Izolacje 2011, nr 3, s. 54-60.

[12] Piłat J., Radziszewski P.: Nawierzchnie asfaltowe. Wydawnictwa Komunikacji i Łączności, Warszawa 2010.

[13] Renaudeau R.: Emulsje asfaltowe i mieszanki „,na zimno”: technologie ekologiczne. Performance 2006, s. 4-5.

[14] Renaudeau R., Rafałowski J.: Technologia ,, slurry surfacing”. Performance 2007, nr 2, s. 14-15.

[15] Stefańczyk B., Mieczkowski P.: Dodatki, katalizatory i emulgatory $w$ mieszankach mineralno-asfaltowych. Wydawnictwa Komunikacji i Łączności, Warszawa 2010.

[16] Szczepaniak Z.: Vademecum kationowych emulsji asfaltowych. Instytut Badawczy Dróg i Mostów, Warszawa 2013.

[17] Szczepaniak Z., Skierczyński P.: Poradnika Laboranta Drogo- wego - kationowe emulsje asfaltowe. IBDiM, Warszawa, marzec 2010.

[18] Szczepaniak Z., Skierczyński P.: Wdrożenie normy europejskiej na kationowe emulsje asfaltowe oraz wdrożenie metod badań kationowych emulsji asfaltowych wedtug 7 norm PN-EN oraz opracowanie „Poradnika Laboranta Drogowego - kationowe emulsje asfaltowe”. Sprawozdanie IBDiM, Warszawa, marzec 2010.

[19] Towarzystwo Naukowo-Badawcze Drogownictwa i Transportu, Grupa robocza ds. robót asfaltowych: Techniczne warunki dostawy emulsji asfaltowych. TL BE-StB 15, kwiecień 2015.

[20] Trzaska E.: Asfalty drogowe - produkcja, klasyfikacja oraz właściwości. Nafta-Gaz 2014, nr 5, s. 325-331.

[21] Trzaska E.: Emulsje asfaltowe. Nafta-Gaz 2016, nr 3, s. 207-212. DOI: 10.18668/NG.2016.03.08.

[22] Trzaska E., Czajkowski P.: Kationowe emulsje asfaltowe. Właściwości lepiszczy odzyskanych i stabilizowanych. Przemysł Chemiczny 2014, t. 93, nr 11, s. 1901-1904.

[23] Trzaska E., Rycaj I.: Wpływ dodatków nowej generacji na właściwości kationowych emulsji asfaltowych. Dokumentacja INiG - PIB, nr archiwalny: DK-411-21/15.

[24] Wyszyński A.: Produkcja i stosowanie kationowych emulsji asfaltowych w Polsce. Nawierzchnie Asfaltowe 2007, nr 2, s. 11-15.

\section{Akty prawne i normatywne}

[25] Norma PN-EN 12591:2010 Asfalty i lepiszcza asfaltowe-Wymagania dla asfaltów drogowych.

[26] Norma PN-EN 13808:2013 Asfalty i lepiszcza asfaltowe - Zasady klasyfikacji kationowych emulsji asfaltowych.

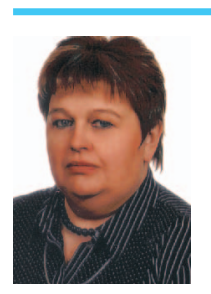

Mgr inż. Elżbieta TRZASKA

Kierownik Laboratorium Olejów, Środków Smarowych i Asfaltów w Zakładzie Olejów, Środków Smarowych i Asfaltów.

Instytut Nafty i Gazu - Państwowy Instytut Badawczy ul. Lubicz 25 A, 31-503 Kraków E-mail: elzbieta.trzaska@inig.pl 